\title{
Insulin-glucocorticoid interactions in the regulation of acetyl-CoA carboxylase- $\alpha$ transcript diversity in ovine adipose tissue
}

\author{
M T Travers and M C Barber \\ Hannah Research Institute, Ayr KA6 5HL, UK \\ (Requests for offprints should be addressed to M C Barber)
}

\begin{abstract}
Transcription of the acetyl-CoA carboxylase (ACC)- $\alpha$ gene is initiated from two promoters, promoter I (PI) and promoter II (PII) such that transcripts demonstrate heterogeneity in their $5^{\prime}$ untranslated regions (UTR). Exons 1 and 2 (E1 and E2) are the primary exons in transcripts initiated from PI and PII respectively; E5 is the first coding exon present in all transcripts. In addition alternative exon splicing results in transcripts that either include or exclude a 47 nucleotide sequence corresponding to $E 4$, such that $E[1 / 4 / 5]$ and $E[1 / 5]$ type transcripts result from PI activity, whereas transcripts containing $\mathrm{E}[2 / 4 / 5]$ or $\mathrm{E}[2 / 5]$ in the 5 'UTR result from PII. In subcutaneous adipose tissue from non-pregnant non-lactating sheep approximately $60 \%$ of $\mathrm{ACC}-\alpha$ transcripts are derived from $\mathrm{PI}$, of which $85 \%$ are the $\mathrm{E}[1 / 5]$ type. Lactation resulted in an $88 \%$ reduction in total PI transcripts, of which the E[1/5] type was reduced $90 \%$ and the $\mathrm{E}[1 / 4 / 5]$ type $80 \%$. By contrast
\end{abstract}

lactation reduced the total levels of PII transcripts by only $50 \%$. Culture of explants from the subcutaneous depot of lactating sheep with insulin plus dexamethasone for $72 \mathrm{~h}$ resulted in an 8-fold increase in both $\mathrm{E}[1 / 4 / 5]$ and $\mathrm{E}[1 / 5]$ types when compared with explants prior to culture. PII transcripts, by contrast, were increased 2 -fold by culture in insulin plus dexamethasone and this was entirely attributed to an increase in the expression of the $E[2 / 4 / 5]$ type. Dexamethasone acts to potentiate the action of insulin on PI and PII transcript abundance and this effect is greatest for PI transcripts. This study has demonstrated that repression of the ACC- $\alpha$ gene in adipose tissue during lactation is largely achieved through attenuation of PI transcript abundance and may be related, in part, to a change in the sensitivity of the apparatus that regulates PI transcript steady-state levels to insulin.

Fournal of Molecular Endocrinology (1999) 22, 71-79

\section{INTRODUCTION}

During late pregnancy and into lactation de novo fatty acid synthesis in adipose tissue is markedly suppressed (Vernon 1988) and the tissue becomes physiologically adapted to release stored lipid as part of a strategy to direct metabolites to the mammary gland for the synthesis and secretion of milk (Barber et al. 1997). Acetyl-CoA carboxylase $(\mathrm{ACC})$, the flux-determining enzyme in the regulation of the lipogenic pathway, exists in isozymic forms that can be partially ascribed to transcription from two distinct genes, ACC- $\alpha$ and ACC- $\beta$ (Luo et al. 1989, Ha et al. 1996). The ACC- $\alpha$ gene gives rise to the $265 \mathrm{kDa}$ isozyme which is expressed in all cell types but demonstrates elevated expression and is the major form in the lipogenic tissues of adipose tissue and liver, and in mammary gland during lactation (Lopez-Casillas et al. 1991, Winz et al. 1994, Abu-Elheiga et al. 1995). ACC- $\beta$, corresponding to the $275-280 \mathrm{kDa}$ isozyme, is the major form in heart and skeletal muscle, where it is implicated in the regulation of fatty acid $\beta$-oxidation in mitochondria (Ha et al. 1996, Abu-Elheiga et al. 1997).

Expression of the ACC- $\alpha$ isozyme is regulated in a complex fashion both in the short term, through allosteric mechanisms and reversible phosphorylation that determines the proportion of active enzyme (Kim et al. 1989), and chronically through regulation of transcription of the gene (Kim \& Tae 1994). Furthermore, transcription of the ACC- $\alpha$ gene is initiated from two promoters, promoter I (PI) and promoter II (PII), resulting in transcripts 
with heterogeneity in the $5^{\prime}$ untranslated region (UTR) (Luo et al. 1989, Ha et al. 1994). Exons 1 and 2 (E1 and E2) are the primary exons in transcripts initiated from PI and PII respectively; E5 is the first coding exon present in all transcripts. In addition, alternative exon splicing results in transcripts that either include or exclude a 47 nucleotide sequence corresponding to $\mathrm{E} 4$ (Luo et al. 1989, Barber \& Travers 1995). PI transcripts are principally expressed in the adipose tissue of freely feeding rats whereas PII transcripts demonstrate a ubiquitous tissue distribution (Lopez-Casillas et al. 1991, Kim et al. 1996).

Previous studies have established that total ACC enzyme activity, the proportion of the enzyme in the active state and the total level of ACC- $\alpha$ transcripts are markedly suppressed in ovine adipose tissue during lactation (Vernon et al. 1991, Travers et al. 1997). The factors responsible for this reduction in lipogenic potential are not completely clear though hypoinsulinaemia together with raised serum growth hormone and insulin resistance of the adipocytes are implicated (Vernon 1988). Indeed, adipose tissue from lactating sheep is initially refractory to stimulation by insulin in vitro, though after $24 \mathrm{~h}$ of culture the rate of fatty acid synthesis, ACC enzyme activity and ACC- $\alpha$ transcript abundance increase markedly (Vernon \& Finley 1988, Vernon et al. 1991, Travers et al. 1997). To delineate this insulin signalling impairment further and to examine the role of $\mathrm{ACC}-\alpha$ promoter usage and transcript diversity in the repression of lipogenic potential in ovine adipose tissue during lactation we have conducted this current study.

\section{MATERIALS AND METHODS}

\section{Animals}

Sheep were Finn-Dorset Horn cross-bred animals, fed on hay and cereals for at least 4 weeks before slaughter as previously described (Vernon et al. 1981). Animals were used either as controls (non-pregnant non-lactating), pregnant or lactating. Pregnant animals were used between days 100 and 105 of gestation, and lactating ewes, suckling at least two lambs, were used at about day 18 of lactation. Animals were anaesthetised and exsanguinated and samples of subcutaneous adipose tissue obtained, snap frozen and stored in liquid nitrogen.

\section{Tissue culture}

Subcutaneous adipose tissue removed aseptically from lactating animals was used to prepare explants. These were maintained in culture in Medium 199 as described previously (Robertson et al. 1982) for $72 \mathrm{~h}$ in combinations of insulin $(17 \mathrm{nM})$ and dexamethasone $(10 \mathrm{nM})$. Fresh explants of adipose tissue and explants after culture were snap frozen and stored in liquid nitrogen.

\section{RNase protection assay}

A 509 nucleotide EcoRI-XhoI fragment corresponding to 242 nucleotides of $\mathrm{E} 1$, the 47 nucleotides of E4 and 220 nucleotides of E5 (Barber \& Travers 1995) was cloned into plasmid pGEM$7 \mathrm{zf}+(\mathrm{p} 1 \mathrm{AEX})$ and used to generate sense transcript with SP6 RNA polymerase and antisense transcript with $\left[\alpha^{32} \mathrm{P}\right] \mathrm{CTP}$ and T7 RNA polymerase (Nielsen \& Shapiro 1986, Kreig \& Melton 1987) (see later Fig. 1B). To measure PII transcripts directly an ACC- $\alpha$ cDNA comprising 21 nucleotide of E2, the 47 nucleotide E4 and 196 nucleotides of E5 was amplified from lactating sheep mammary gland cDNA by $5^{\prime}$ rapid amplification of $\mathrm{cDNA}$ ends PCR (RACE-PCR) (Frohman et al. 1988). Briefly, total RNA was isolated from lactating sheep mammary gland using guanidinium isothiocyanate and centrifugation through caesium chloride (Chirgwin et al. 1979). cDNA was prepared from $2 \mu \mathrm{g}$ of this RNA using MMLV reverse transcriptase (GibcoBRL, Paisley, Strathclyde, UK), and the synthesis primed with an oligonucleotide (5' CTTTCGGT CTCGACCTTG) antisense to nucleotides +579 to +595 of the ovine ACC- $\alpha$ cDNA (Barber \& Travers 1995). Due to the high GC content (greater than $80 \%$ ) found at the $5^{\prime}$ end of the previously cloned rat ACC- $\alpha$ cDNA (Luo et al. 1989), RNA was denatured at $90{ }^{\circ} \mathrm{C}$ for 2 min before annealing of the primer and extension of the cDNA at $42{ }^{\circ} \mathrm{C}$ using the conditions recommended by the manufacturer. Single-stranded cDNA was purified through Sephadex G-50 and precipitated. After centrifugation and drying, the cDNA was $3^{\prime}$ tailed with dATP using terminal transferase. Approximately one-quarter of the cDNA was used to amplify a region of DNA using a downstream primer corresponding to nucleotides +464 to +491 of the ovine ACC- $\alpha$ cDNA (5' TCTGAGCTGACAG AGGCTGGTGACAG), a T-adaptor primer (5' GACTCGAGTCGACATCGATTTTTTTTTT TTTTTTT) and an adaptor primer (5' GACTC GAGTCGACATCG) (Frohman et al. 1988). After an initial denaturation at $94{ }^{\circ} \mathrm{C}$ for $5 \mathrm{~min}, 35$ cycles of amplification were carried out as follows: denaturation at $92{ }^{\circ} \mathrm{C}$ for $30 \mathrm{~s}$, annealing at $55^{\circ} \mathrm{C}$ for $30 \mathrm{~s}$, and extension at $72{ }^{\circ} \mathrm{C}$ for $30 \mathrm{~s}$. One-tenth of the product was then resolved on a $1 \%(\mathrm{w} / \mathrm{v})$ agarose/TBE gel and visualised by ethidium bromide staining. The remainder of the product 
was purified using a Promega Wizard PCR clean-up kit (Promega, Southampton, Hants, UK), ligated into the pDK101 cloning vector (Kovalic et al. 1991) and used to transform competent JM109 cells (Hanahan 1985). Antisense transcripts were synthesised from a single recombinant (p3E2) (Fig. 1C) with SP6 RNA polymerase.

Tissue samples were powdered in a mortar and pestle using liquid nitrogen and homogenised in $5 \mathrm{M}$ guanidinium isothiocyanate, $100 \mathrm{mM}$ EDTA, $\mathrm{pH} 7 \cdot 0$, using a constant tissue to volume ratio. Aliquots $(40 \mu \mathrm{l})$ of these were hybridised to the antisense cRNA and subsequently digested using RNaseA/RNase T1 and proteinase $\mathrm{K}$ as described by Firestein et al. (1987). In addition standard amounts of sense transcript were hybridised to the antisense transcript as positive controls. After extraction with phenol and chloroform the samples were precipitated twice and rinsed with $80 \%(\mathrm{v} / \mathrm{v})$ alcohol. Samples were dried, resuspended and, after denaturing in formamide loading buffer at $85^{\circ} \mathrm{C}$, resolved on a $6 \%(\mathrm{w} / \mathrm{v})$ acrylamide/7 M urea sequencing gel (Maniatis et al. 1975). After drying, the gels were exposed to a Kodak phosphor screen overnight. The resulting images were scanned using a Molecular Dynamics (Sunnyvale, CA, USA) phosphorimager $445 \mathrm{SI}$ and the volume of individual bands obtained using ImageQuant software (Molecular Dynamics). DNA content of the homogenates was measured by a modification of the method of Labarca \& Paigen (1980). In this, tissue samples were homogenised in $5 \mathrm{M}$ guanidinium isothiocyanate, $100 \mathrm{mM}$ EDTA, $\mathrm{pH} 7 \cdot 0$, and extracted with four volumes of water-saturated chloroform before being assayed as described.

\section{Measurement of the rate of fatty acid synthesis}

The rate of fatty acid synthesis in cultured adipose explants was determined from the amount of incorporation of $\left[{ }^{14} \mathrm{C}\right]$ acetate $(1 \mu \mathrm{Ci} / \mathrm{ml}$ culture medium $)$ into total lipid over a $4 \mathrm{~h}$ incubation. Tissue was homogenised in $5 \mathrm{M}$ guanidinium isothiocyanate, $100 \mathrm{mM}$ EDTA, pH 7.0 and total lipid was extracted with an equal volume of water-saturated chloroform, the chloroform phase collected and evaporated and the samples scintillation counted.

\section{RESULTS}

Two RNase protection assays were established (Fig. 1) to evaluate the contribution of PI and PII (Fig. 1A) activity to total ACC- $\alpha$ mRNA in ovine adipose tissue. p1AEX (Fig. 1B) comprises
E1+E4+E5; full-length protected fragments (509 nucleotides) correspond to E[1/4/5] type transcripts whereas $E[1 / 5]$ type transcripts are represented by the E1 (242 nucleotides)+E5 (220 nucleotides) portions of the probe in equimolar amounts. PII transcripts are represented by the E4+E5 (E[2/4/5]; 267 nucleotides) and the $\mathrm{E} 5(\mathrm{E}[2 / 5])$ protected fragments. To confirm these deductions about PII transcripts an RNase protection assay based on p3E2, a plasmid comprising a 264 nucleotide sequence corresponding to $\mathrm{E} 2+\mathrm{E} 4+\mathrm{E} 5$ was also used (Fig. 1C) in separate assays.

Figure 2 demonstrates use of the p1AEX (Fig $2 a$ and $b$ ) and p3E2 (Fig. 2c) RNase protection assays on adipose tissue homogenates from non-pregnant non-lactating, pregnant and lactating sheep, and from tissue from lactating sheep cultured with insulin plus dexamethasone. Data from these assays were normalised to take into account the contribution of each of the protected fragments in molar terms and for the DNA content of the homogenates (Table 1). In subcutaneous adipose tissue from non-pregnant non-lactating sheep, approximately $60 \%$ of ACC- $\alpha$ transcripts were derived from PI, of which $85 \%$ are the E[1/5] type. Pregnancy and the subsequent lactation resulted in an $88 \%$ reduction in PI transcripts $(P<0 \cdot 001)$, of which the $\mathrm{E}[1 / 5]$ type was reduced by $90 \%(P<0 \cdot 001)$ and the $\mathrm{E}[1 / 4 / 5]$ type by $80 \%(P<0 \cdot 001)$. By contrast pregnancy and lactation reduced the total levels of PII transcripts by only $50 \%(P<0 \cdot 001)$ with the greatest suppression being observed in the level of expression of the $\mathrm{E}[2 / 4 / 5]$ splice variant. Repression of ACC- $\alpha$ transcripts was evident by 100 days of pregnancy and maintained into lactation. Culture of explants from the subcutaneous depot of lactating sheep with insulin plus dexamethasone for $72 \mathrm{~h}$ resulted in an 8 -fold increase $(P<0 \cdot 001)$ in both $\mathrm{E}[1 / 4 / 5]$ and $\mathrm{E}[1 / 5]$ types when compared with explants prior to culture. PII transcripts, by contrast, were increased approximately 2 -fold $(P<0 \cdot 01)$ by culture with insulin plus dexamethasone and this was entirely attributed to an approximately 4 -fold increase $(P<0 \cdot 001)$ in the expression of the E[2/4/5] type (Table 1 ). Direct measurement of the $E[2 / 4 / 5]$ transcript with the p3E2 riboprobe (Fig. 2c) confirmed the magnitude of the induction of this mRNA in explant culture with insulin plus dexamethasone (data not shown). Maintenance of adipose tissue explants in culture for $72 \mathrm{~h}$ in the absence of exogenous hormones resulted in a level of ACC- $\alpha$ transcripts similar to that of the freshly prepared explants.

In a second study, to determine the separate roles of insulin and dexamethasone in the induction of ACC- $\alpha$ transcripts in adipose tissue explants from lactating sheep, it was observed that culture with 
A

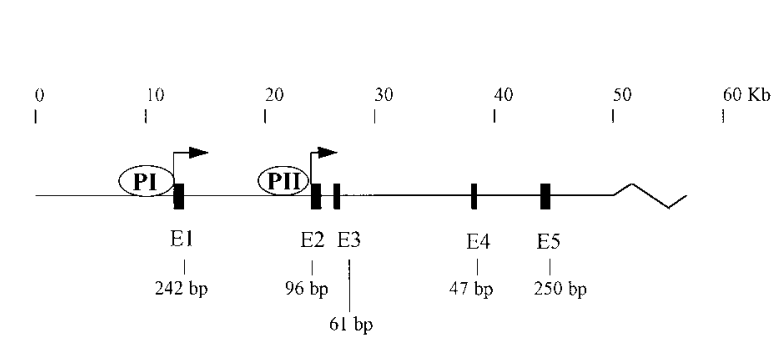

B

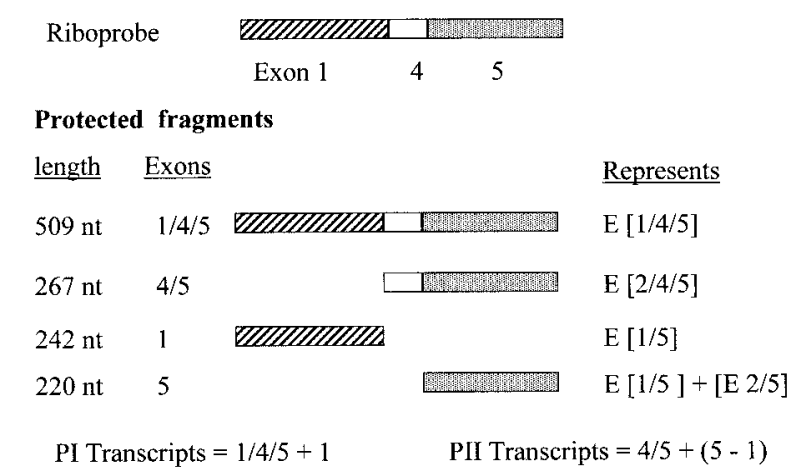

C

Riboprobe

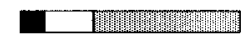

Exon $24 \quad 5$

Protected fragments

$\begin{array}{llll}\text { length } & \text { Exons } & & \text { Represents } \\ 264 \mathrm{nt} & 2 / 4 / 5 & \text { E [2/4/5] } \\ 243 \mathrm{nt} & 4 / 5 & \square & \text { E [1/4/5] } \\ 196 \mathrm{nt} & 5 & & \text { E [1/5]+E E [2/5] }\end{array}$

FIGURE 1. Diagrammatic representation of the promoter structure of the ACC- $\alpha$ gene (A) and the basis for the ribonuclease protection assays used to quantitatively determine the relative abundances of $\mathrm{ACC}-\alpha$ transcripts arising from either PI or PII in ovine adipose tissue (B and C). (A) PI and PII of the rat ACC- $\alpha$ gene are shown adjacent to the primary exons of ACC- $\alpha$ mRNA. E1 and E2 are the primary exons in transcripts initiated from PI and PII respectively. E5 is the first coding exon present in all transcripts initiated from PI or PII. Exons downstream of E5 have not been characterised. Alternative exon splicing results in transcripts that either include or exclude E4 such that $\mathrm{E}[1 / 4 / 5]$ and $\mathrm{E}[1 / 5]$ type transcripts result from PI activity whereas transcripts containing $\mathrm{E}[2 / 4 / 5]$ or $\mathrm{E}[2 / 5]$ in the $5^{\prime} \mathrm{UTR}$ result from PII. Transcripts containing E3 sequences are present as a minor species in lactating rat mammary gland (Lopez-Casillas et al. 1989). (B) A 509 nucleotide EcoRI-XhoI fragment (p1AEX) corresponding to 242 nucleotides of $\mathrm{E} 1$, the 47 nucleotides of $\mathrm{E} 4$ and 220 nucleotides of $\mathrm{E} 5$ was used in an RNase protection assay. Full-length protected fragments of 509 nucleotides correspond to E[1/4/5] type mRNA. Hybridisation of the riboprobe with $\mathrm{E}[1 / 5]$ type mRNA results in the $\mathrm{E} 4$ portion of the probe being 'looped' out of the hybrid making it susceptible to digestion with RNase; this results in protected fragments of 242 nucleotides corresponding to E1 and 220 nucleotides corresponding to E5. Similarly hybridisation of the riboprobe with E[2/4/5] type mRNA results in protection of the E4 plus E5 portion of the probe (267 nucleotides). Hybrid formation with E[2/5] type mRNA results in protection of the E5 portion of the probe only. E[2/5] mRNA is determined by subtracting the $\mathrm{E}[1 / 5]$ contribution to the 220 nucleotide fragment corresponding to E5. (C) To measure E[2/4/5] type mRNA directly in RNase protection assays an ACC- $\alpha$ cDNA comprising 21 nucleotides of E2, the 47 nucleotide E4 and 196 nucleotides of E5 was amplified from lactating sheep mammary gland cDNA by $5^{\prime}$ RACE-PCR (p3E2). Full-length protected fragments of 264 nucleotides correspond to E[2/4/5] type ACC- $\alpha$ mRNA. Hybrid formation with E[1/4/5] type mRNA results in the protection of the E4 plus E5 portion of the riboprobe (243 nucleotides) only. Protection of the E5 portion of the riboprobe only (196 nucleotides) arises from both E[2/5] and E[1/5] type mRNA.

insulin alone for $72 \mathrm{~h}$ increased the abundance of both PI and PII transcripts approximately 2-fold $(P<0 \cdot 01)$ compared with culture with no added hormones for the same period; expression of the $\mathrm{E}[1 / 5]$ and $\mathrm{E}[2 / 4 / 5]$ splice variants was most enhanced by culture in insulin (Fig. $3 a$ and $b$ ).
Culture with dexamethasone alone for $72 \mathrm{~h}$ had no effect on the total levels of PI and PII transcripts or in the pattern of splice variants expressed, compared with culture with no added hormones for the same period. Culture with insulin plus dexamethasone resulted in an approximately 


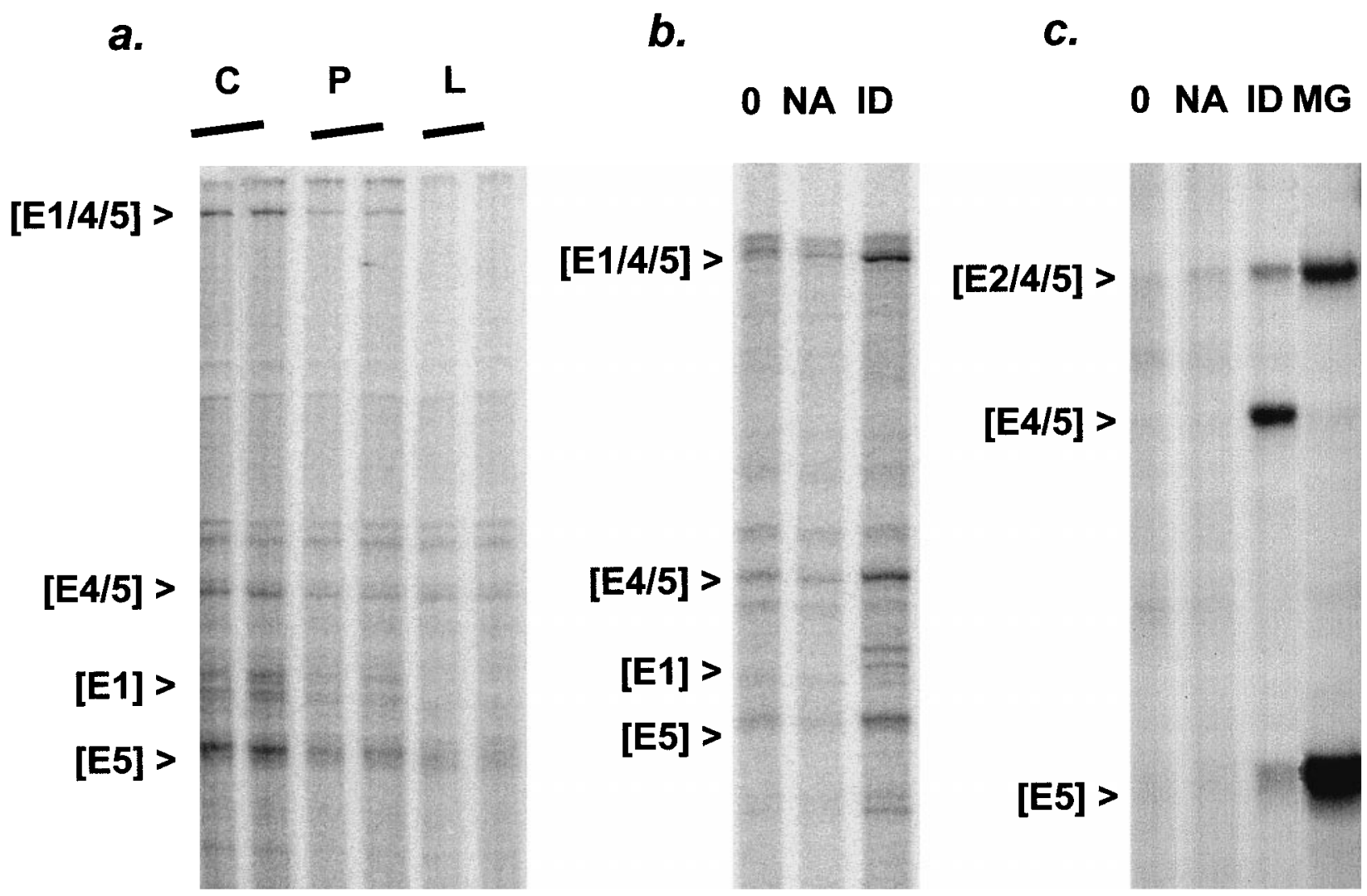

FIGURE 2. Expression of ACC- $\alpha$ transcripts in adipose tissue during pregnancy and lactation and in explants from lactating sheep cultured with insulin plus dexamethasone. Homogenates were prepared from subcutaneous adipose tissue from non-pregnant non-lactating (C), 100-105 day pregnant (P) and lactating (L) animals, and from subcutaneous adipose explants from lactating sheep at time zero (0) and after culture for $72 \mathrm{~h}$ with no hormones (NA) or insulin plus dexamethasone (ID). These were used in an RNase protection assay with antisense ACC transcript corresponding to E1, 4 and $5(a$ and $b)$ and E2, 4 and $5(c)$. The basis and interpretation of these assays is illustrated in Fig. 1. In $(c)$ the inclusion of lactating sheep mammary gland (MG) homogenate demonstrates the presence of E[2/4/5] type mRNA but little E[1/4/5] transcript as represented by the E4 plus E5 portion of the riboprobe. The protected fragments were quantified using a phosphorimager with ImageQuant software. Transcripts corresponding to E[1/4/5], E[1/5], E[2/4/5] and E[2/5] ACC- $\alpha$ mRNA were determined (Fig. 1) and expressed as arbitrary units/mg tissue DNA (Table 1).

$4 \cdot 5$-fold $(P<0 \cdot 001)$ increase in both $\mathrm{E}[1 / 4 / 5]$ and $\mathrm{E}[1 / 5]$ transcripts compared with culture with insulin alone. By comparison culture with insulin plus dexamethasone resulted in a further $1 \cdot 5$-fold increase in total PII transcripts compared with culture with insulin alone, and this was entirely achieved through an increase in the $\mathrm{E}[2 / 4 / 5]$ variant (Fig. $3 a$ and $b$ ) as demonstrated above (Table $1)$. Thus dexamethasone acts to potentiate the action of insulin on PI and PII transcript abundance and this effect is greatest for PI transcripts. By contrast, culture with insulin alone stimulated the rate of fatty acid synthesis in adipose explants approximately 3 -fold $(P<0 \cdot 001)$ compared with culture with no added hormones and this was stimulated a further 2 -fold by culture with insulin plus dexamethasone (Table 2).

\section{DISCUSSION}

A major feature of the repression of the ACC- $\alpha$ gene in adipose tissue during late pregnancy and into lactation is that it is largely promoter specific. The levels of PI transcripts are potently repressed whereas those of PII are diminished only to a relatively minor extent. It is important to note, however, that the RNase protection assays used in this study measure the steady-state levels of ACC- $\alpha$ transcripts derived from PI and PII, and thus the 
TABLE 1. Expression of PI and PII ACC- $\alpha$ transcripts in adipose tissue during pregnancy and lactation and in explants from lactating sheep cultured with insulin plus dexamethasone. Homogenates were prepared from subcutaneous adipose tissue from non-pregnant non-lactating, 100-105 day pregnant and lactating animals, and from subcutaneous adipose explants from lactating sheep at time zero and after culture for $72 \mathrm{~h}$ with no hormones or insulin plus dexamethasone. These were used in an RNase protection assay with antisense ACC transcript corresponding to exons 1,4 and 5. Transcripts corresponding to $E[1 / 4 / 5], E[1 / 5], E[2 / 4 / 5]$ and $E[2 / 5] \mathrm{ACC}-\alpha$ mRNA were determined (Fig. 1) and expressed as arbitrary units/mg tissue DNA. Values were analysed by ANOVA and are the means \pm s.E.M. of $n$ observations

Tissue in vivo

\begin{tabular}{lll}
$\begin{array}{l}\text { Control } \\
(n=13)\end{array}$ & $\begin{array}{l}\text { Pregnant } \\
(n=4)\end{array}$ & $\begin{array}{l}\text { Lactating } \\
(n=9)\end{array}$ \\
\hline
\end{tabular}

Transcript type

$\mathrm{E}[1 / 4 / 5]$

$\mathrm{E}[1 / 5]$

$\mathrm{E}[2 / 4 / 5]$

$\mathrm{E}[2 / 5]$

$\begin{aligned} 364 & \pm 99 \\ 2158 & \pm 466 \\ 726 & \pm 117 \\ 1021 & \pm 162\end{aligned}$

$78 \pm 25^{\dagger+\dagger}$

$350 \pm 152^{\dagger+\dagger}$

$139 \pm 50^{+\dagger \dagger}$

$623 \pm 63^{\dagger+\dagger}$
Explants in culture

\begin{tabular}{|c|c|c|}
\hline $\begin{array}{l}\text { Time zero } \\
(n=9)\end{array}$ & $\begin{array}{l}\text { No hormone } \\
(n=9)\end{array}$ & $\begin{array}{l}\text { Insulin + dexamethasone } \\
(n=9)\end{array}$ \\
\hline $127 \pm 52$ & $17 \pm 7$ & $1050 \pm 315$ **** \\
\hline $288 \pm 60$ & $512 \pm 199$ & $2316 \pm 480 * * * *$ \\
\hline $456 \pm 42$ & $682 \pm 127$ & $1726 \pm 302 * * * *$ \\
\hline $429 \pm 65$ & $359 \pm 84$ & $430 \pm 131$ \\
\hline
\end{tabular}

${ }^{\dagger \dagger}$ Means significantly different $(P<0 \cdot 001)$ when pregnant animals are compared with non-lactating animals. ******* Means significantly different $(P<0 \cdot 001$ and $P<0 \cdot 01$ respectively) when lactating animals are compared with non-pregnant non-lactating animals, and when adipose tissue explants cultured with insulin plus dexamethasone are compared with explants at zero time or after culture with no hormones.

observed levels of transcripts reflect the interaction of transcription, mRNA stability and processing components rather than transcriptional activity alone. The physiological significance of the dual promoter system is unclear at present but may relate in part to the specialisation of adipocytes for fatty acid synthesis and storage, a function distinct from the synthesis of fatty acids for incorporation into cell membranes. PI transcripts are principally expressed in the adipose tissue of freely fed rats whereas PII transcripts exhibit a ubiquitous distribution (Kim et al. 1996). Furthermore, the elevated hepatic lipogenesis that occurs through starving and refeeding rats a high carbohydrate diet or in pathological conditions such as the genetically obese $f a / f a$ Zucker rat is associated with the emergence of hepatic PI transcripts (Lopez-Casillas et al. 1991, 1992). The specific repression of PI in ovine adipose tissue during lactation when lipogenesis is suppressed (Vernon et al. 1981) and the tissue becomes adapted to release stored lipid as part of a strategy to direct metabolites to the mammary gland (Barber et al. 1997) is consistent with this hypothesis. However, only $5-10 \%$ of the cells that comprise adipose tissue in sheep are adipocytes (Travers et al. 1997). This raises some concerns that the PI and PII activities may actually reside in separate cell types and that the specificity of PI repression may be achieved at the level of a cell membrane receptor. However, fractionation of adipose tissue into the stromovascular cells (endothelial cells and fibroblasts) and an adipocyteenriched fraction demonstrated that PI transcripts are exclusively associated with the adipocytes whereas PII transcripts are associated with both fractions, though the level of expression is markedly higher in the adipocyte fraction (results not shown). This implies that the majority of PII activity also resides in adipocytes and consequently the specificity of PI repression arises as a result of the chromatin configuration in the vicinity of the PI promoter.

Repression of the ACC- $\alpha$ gene is a major factor in the suppression of fatty acid synthesis in adipose tissue that occurs during pregnancy and into lactation and is associated with a decline in serum insulin concentrations and the development of insulin insensitivity by the tissue (Vernon et al. 1981, Travers et al. 1997, Guesnet et al. 1991). Such insensitivity to insulin manifests itself in vitro by a lag phase of 24-32 h before the induction of the rate of fatty acid synthesis, an increase in the proportion of ACC enzyme in the active state, induction of total ACC enzyme activity and increases in the levels of ACC- $\alpha$ mRNA by culture with insulin plus dexamethasone are observed (Vernon \& Finley 1988, Vernon et al. 1991, Travers et al. 1997). This present study has further shown that the diminished level of PI ACC- $\alpha$ transcripts in adipose tissue from lactating sheep can be potently stimulated by culture of explants with insulin plus dexamethasone; PII transcripts are also increased though to a lesser extent. Interestingly, culture with insulin plus dexamethasone also promotes the inclusion of a sequence corresponding to E4 into transcripts such that the increase in PII transcripts is almost entirely due to the increase in the $\mathrm{E}[2 / 4 / 5]$ species. Furthermore, relative to adipose tissue from 
a

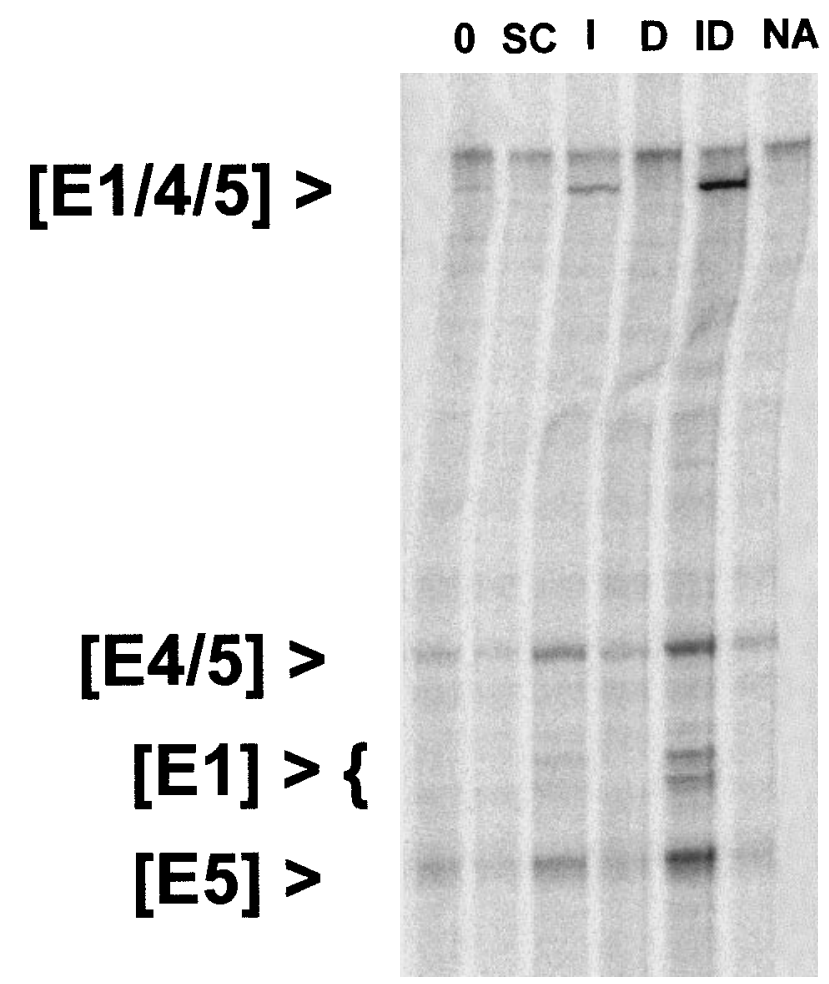

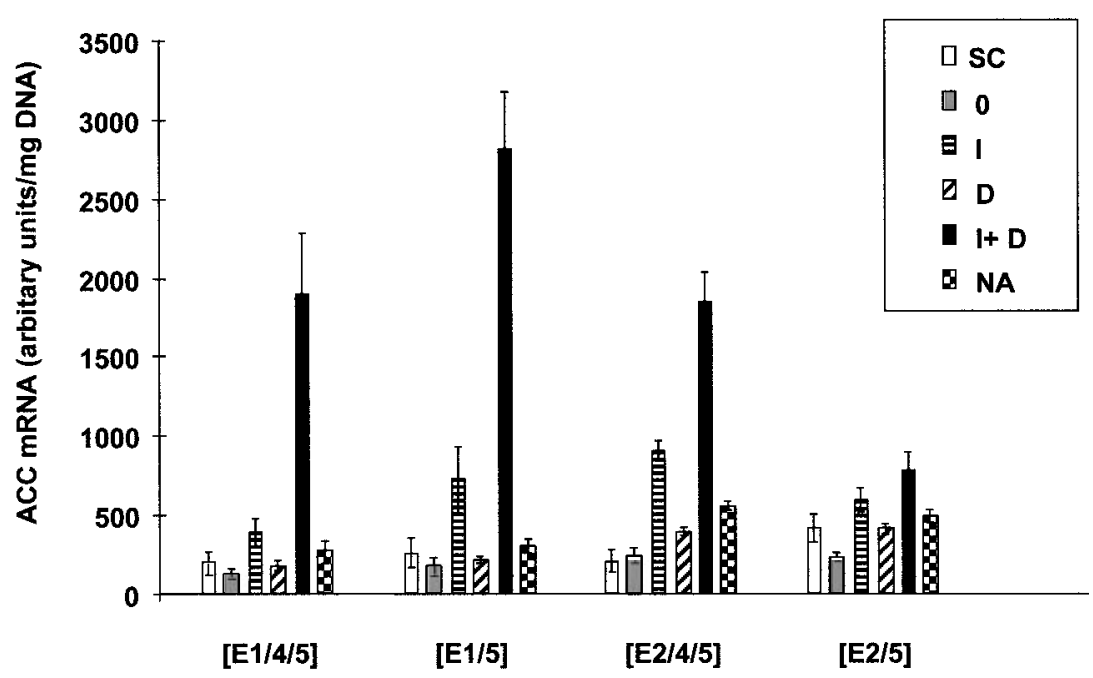

FIGURE 3. Effect of tissue culture in the presence of combinations of insulin and dexamethasone on the expression of ACC- $\alpha$ transcripts in subcutaneous adipose tissue explants from lactating sheep. Homogenates were prepared from subcutaneous adipose tissue of lactating sheep (SC) and from the same tissue cultured for $72 \mathrm{~h}$ in combinations of insulin (I) and dexamethasone (D) or no additions (NA). Zero (0) corresponds to homogenates made from explants prior to culture. These were used in an RNase protection assay with antisense ACC transcript corresponding to E1, 4 and $5(a)$. The protected fragments were quantified using a phosphorimager with ImageQuant software. Transcripts corresponding to E[1/4/5], E[1/5], E[2/4/5] and E[2/5] ACC- $\alpha$ mRNA were determined (Fig. 1) and expressed as arbitrary units/mg tissue DNA $(b)$. Values are the means \pm s.E.M. of four observations. 
TABLE 2. Effects of tissue culture in the presence of combinations of insulin and dexamethasone on the rate of fatty acid synthesis ( $\mu$ mol acetate incorporated/4 h per mg tissue DNA) by subcutaneous adipose tissue explants from lactating sheep. Tissue was maintained in culture for $72 \mathrm{~h}$ in combinations of insulin and dexamethasone or no additions before measurement of the rate of fatty acid synthesis. The time zero value corresponds to the rate of lipogenesis in freshly prepared explants prior to culture. Values were analysed by ANOVA and are the means \pm s.E.M. of four observations

\begin{tabular}{|c|c|c|c|c|}
\hline $\begin{array}{l}\text { Time } \\
\text { zero }\end{array}$ & $\begin{array}{l}\text { No } \\
\text { hormone }\end{array}$ & Insulin & Dexamethasone & Insulin + dexamethasone \\
\hline $\begin{array}{r}2 \cdot 3 \\
\pm 0 \cdot 1\end{array}$ & $\begin{array}{r}2.8 \\
\pm 0.4\end{array}$ & $\begin{aligned} & 6.7 \text { **** } \\
\pm & 0.9\end{aligned}$ & $\begin{array}{r}2 \cdot 3 \\
\pm 0 \cdot 2\end{array}$ & $\begin{aligned} & 13 \cdot 7^{\dagger \dagger \dagger} \\
\pm & 1 \cdot 9\end{aligned}$ \\
\hline
\end{tabular}

**** Means significantly different $(P<0 \cdot 001)$ when cultures in insulin are compared with zero time; ${ }^{+}{ }^{\dagger}$ means significantly different $(P<0 \cdot 001)$ when cultures in insulin +dexamethasone are compared with insulin.

non-pregnant non-lactating animals the ratio of $\mathrm{E}[1 / 4 / 5]$ to $\mathrm{E}[1 / 5]$ transcripts is also increased by culture with insulin plus dexamethasone. Together, these suggest that the splicing mechanism that results in the inclusion of $\mathrm{E} 4$ into $\mathrm{ACC}-\alpha$ transcripts is regulated in part by the action of insulin. Sequences corresponding to E4 are well conserved from chicken to man and alternative exon splicing of $\mathrm{E} 4$ has been demonstrated in a number of species (Lopez-Casillas et al. 1989, Ha et al. 1994, Barber \& Travers 1995). In contrast to our findings in ovine adipose tissue, in which transcripts that lack E4 predominate, the majority of ACC- $\alpha$ transcripts in rat tissues, including adipose tissue (LopezCasillas et al. 1991) and in chicken liver appear to include E4 (El Khadir-Mounier et al. 1996). Thus, the significance of transcript heterogeneity due to the inclusion or exclusion of $\mathrm{E} 4$ in $\mathrm{ACC}-\alpha \mathrm{mRNA}$ is unclear at present and remains to be determined.

This present study has demonstrated synergy between glucocorticoid and insulin on the abundance of ACC- $\alpha$ transcripts and that potentiation of insulin action by glucocorticoid is considerably more marked for PI than for PII transcripts. In this respect, the effect of the interaction between glucocorticoid and insulin on the transcript steadystate levels could be exerted through increased transcription or result in mRNA stabilisation, or a combination of both. Further work will be required to distinguish between these possibilities. However, the machinery that regulates the pattern of $5^{\prime} \mathrm{UTR}$ ACC- $\alpha$ splice variants appears to be determined by the action of insulin alone as the relative pattern of the transcripts is not further modulated by insulin plus dexamethasone. Furthermore, a previous study has demonstrated that glucocorticoid potentiates, in vitro in adipose explants from lactating sheep, the action of insulin on the proportion of ACC in the active state (Vernon et al. 1991). Thus insulinglucocorticoid interaction is evident at both the level of ACC- $\alpha$ gene expression and the enzymatic machinery. Whether the interaction occurs prior to the bifurcation of the signal to the gene expression and enzymatic components or at each locus independently remains to be established. In contrast to serum insulin, glucocorticoid concentrations tend to rise with lactation in both ruminants and non-ruminants (Cowie et al. 1980) thus implying that insulin responsiveness per se is pivotal to the lipogenic suppression in adipose tissue. However, insulin-glucocorticoid interaction at key points of the lipogenic pathway may result in those points being most sensitive to the fall in serum insulin that occurs in late pregnancy (Vernon et al. 1981). This may partially explain the relative repression of ACC- $\alpha$ PI transcripts compared with those of PII that occurs in adipose tissue during lactation. However, growth hormone, which is potently insulin antagonistic and thus anti-lipogenic in sheep adipose tissue in vitro (Vernon \& Finley 1988, Vernon et al. 1991, Borland et al. 1994) and in rodent adipocyte cell lines (Schwartz \& Carter-Su 1988), increases in concentration markedly during lactation in sheep (Vernon et al. 1981) and may impart changes in the pattern of gene expression that result in the attenuation of the insulin signal to specific components of the lipid synthetic machinery of the adipocyte. This study has demonstrated that one of those targets results in the potent repression of $\mathrm{ACC}-\alpha \mathrm{PI}$ transcript abundance.

\section{ACKNOWLEDGEMENTS}

The authors thank Mrs Helen Pollock and Mrs Mandy Vallance for expert technical assistance. This 
work was funded by the Scottish Office Agriculture Environment and Fisheries Department.

\section{REFERENCES}

Abu-Elheiga L, Jayakumar A, Baldini A, Chirala SS \& Wakil SJ 1995 Human acetyl-CoA carboxylase - characterisation, molecular-cloning, and evidence for 2 isoforms. Proceedings of the National Academy of Sciences of the USA 92 4011-4015.

Abu-Elheiga L, Almarza-Ortega DB, Baldini A \& Wakil SJ 1997 Human acetyl-CoA carboxylase 2: molecular cloning, characterisation, chromosomal mapping and evidence for two isoforms. Fournal of Biological Chemistry 272 10669-10677.

Barber MC \& Travers MT 1995 Cloning and characterisation of multiple acetyl-CoA carboxylase transcripts in ovine adipose tissue. Gene 154 271-275.

Barber MC, Clegg RA, Travers MT \& Vernon RG 1997 Lipid metabolism in the lactating mammary gland. Biochimica et Biophysica Acta 1347 101-126.

Borland CA, Barber MC, Travers MT \& Vernon RG 1994 Growth hormone inhibition of lipogenesis in sheep adipose tissue: requirement for gene transcription and polyamines. Fournal of Endocrinology 142 235-243.

Chirgwin JM, Przbyla AE, MacDonald RJ \& Rutter WJ 1979 Isolation of biologically active ribonucleic acid from sources enriched in ribonuclease. Biochemistry 18 5294-5299.

Cowie AT, Forsyth IA \& Hart IC 1980 In Hormonal Control of Lactation, pp 165-188. Eds AT Cowie, IA Forsyth \& IC Hart. Berlin: Springer-Verlag.

El Khadir-Mounier C, Lefur N, Powell RS, Diot C, Langlois P, Mallard J \& Douaire M 1996 Cloning and characterisation of the $5^{\prime}$ end and promoter region of the chicken acetyl-CoA carboxylase gene. Biochemical Fournal 314 613-619.

Firestein GS, Gardner SM \& Roeder WD 1987 Quantitative molecular hybridization with unfractionated, solubilized cells using RNA probes and polyacrylamide gel electrophoresis. Analytical Biochemistry 167 381-386.

Frohman MA, Dush MK \& Martin GR 1988 Rapid production of full-length cDNAs from rare transcripts - amplification using a single-gene specific oligonucleotide primer. Proceedings of the National Academy of Sciences of the USA 85 8998-9002.

Guesnet PM, Massoud MJ \& Demarne Y 1991 Regulation of adipose tissue metabolism during pregnancy and lactation in the ewe: the role of insulin. Fournal of Animal Science 69 $2057-2065$.

Ha J, Daniel S, Kong IS, Park CK, Tae HJ \& Kim KH 1994 Cloning of human acetyl-CoA carboxylase cDNA. European Fournal of Biochemistry 219 297-306.

Ha J, Lee JK, Kim KS, Witters LA \& Kim KH 1996 Cloning of human acetyl-CoA carboxylase- $\beta$ and its unique features. Proceedings of the National Academy of Sciences of the USA 93 11466-11470.

Hanahan D 1985 In DNA Cloning, vol 1, pp 109-136. Ed. DM Glover. Oxford: IRL press.

Kim KH \& Tae HJ 1994 Pattern and regulation of acetyl-CoA carboxylase gene expression. Fournal of Nutrition 124 $1273 \mathrm{~S}-1283 \mathrm{~S}$

Kim KH, Lopez-Casillas F, Bai DH, Luo X \& Pape ME 1989 Role of reversible phosphorylation of acetyl-CoA carboxylase in long chain fatty acid synthesis. FASEB Fournal 3 2250-2256.
Kim TS, Leahy P \& Freake HC 1996 Promoter usage determines tissue specific responsiveness of the rat acetylCoA carboxylase mRNA. Biochemical and Biophysical Research Communications 225 647-653.

Kovalic D, Kwak JH \& Weisblum B 1991 General method for direct cloning of DNA fragments generated by the polymerase chain reaction. Nucleic Acids Research 194560.

Kreig PA \& Melton DA 1987 In vitro RNA synthesis with SP6 RNA polymerase. Methods in Enzymology 155 397-415.

Labarca C \& Paigen K 1980 A simple rapid and sensitive DNA assay procedure. Analytical Biochemistry 102 344-352.

Lopez-Casillas F, Luo X, Kong IS \& Kim KH 1989 Characterisation of different forms of rat mammary gland acetyl-CoA carboxylase mRNA: analysis of heterogeneity at the $5^{\prime}$ end. Gene 83 311-319.

Lopez-Casillas F, Ponce-Castaneda MV \& Kim KH 1991 In vivo regulation of the activity of the two promoters of the rat acetyl coenzyme-A carboxylase gene. Endocrinology 129 $1049-1058$

Lopez-Casillas F, Ponce-Castaneda MV \& Kim KH 1992 Acetyl-coenzyme-A carboxylase messenger-RNA metabolism in the rat-liver. Metabolism: Clinical and Experimental $\mathbf{4 1}$ 201-207.

Luo X, Park K, Lopez-Casillas F \& Kim KH 1989 Structural features of the acetyl-CoA carboxylase gene: mechanisms for the generation of mRNAs with $5^{\prime}$ end heterogeneity. Proceedings of the National Academy of Sciences of the USA 86 4042-4046.

Maniatis T, Jeffrey A \& van deSand H 1975 Chain length determination of small double and single-stranded DNA molecules by polyacrylamide gel electrophoresis.

Biochemistry 14 3787-3794.

Nielsen DA \& Shapiro DJ 1986 Preparation of capped RNA transcripts using T7 RNA-polymerase. Nucleic Acids Research 145936.

Robertson JP, Faulkner A \& Vernon RG 1982 Regulation of glycolysis and fatty acid synthesis from glucose in sheep adipose tissue. Biochemical fournal 206 577-586.

Schwartz J \& Carter-Su C 1988 Effects of growth hormone on glucose metabolism and glucose transport in 3T3-F442A cells: Dependence on cell differentiation. Endocrinology 122 2247-2256.

Travers MT, Vernon RG \& Barber MC 1997 Repression of the acetyl-CoA carboxylase gene in ovine adipose tissue during lactation: the role of insulin responsiveness. Fournal of Molecular Endocrinology 19 99-107.

Vernon RG 1988 In Nutrition and Lactation in the Dairy Cow, pp 32-52. Ed. PC Garnsworthy. London: Butterworths Ltd.

Vernon RG \& Finley E 1988 Roles of insulin and growth hormone in the adaptations of fatty acid synthesis in white adipose tissue during the lactation cycle in sheep. Biochemical Fournal 256 873-878.

Vernon RG, Clegg RA \& Flint DJ 1981 Metabolism of sheep adipose tissue during pregnancy and lactation: adaptation and regulation. Biochemical Fournal 200 307-314.

Vernon RG, Barber MC \& Finley E 1991 Modulation of the activity of acetyl-CoA carboxylase and other lipogenic enzymes by growth hormone, insulin and dexamethasone in sheep adipose tissue and relationship to adaptations to lactation. Biochemical Fournal 274 543-548.

Winz R, Hess D, Aebersold R \& Brownsey RW 1994 Unique structural features and differential phosphorylation of the $280-\mathrm{kDa}$ component (isozyme) of rat liver acetyl-CoA carboxylase. Fournal of Biological Chemistry 269 365-371.

RECEIVED 8 June 1998 